\title{
Accounting
}

\section{Past performance and earning management: The moderating effect of employee relative earning}

\author{
Ronny Kountur ${ }^{\mathrm{a}^{*}}$, Bramantyo Djohanputro ${ }^{\mathrm{a}}$ and Martdian Ratna Sari ${ }^{\mathrm{a}}$
}

${ }^{a} P$ PM School of Management, Indonesia

\section{H R O N I C L E}

\section{Article history:}

Received: August 23, 2020

Received in revised format:

October 302020

Accepted: November 16, 2020

Available online:

November 16, 2020

Keywords:

Earning Management

Past Performance

Employee Relative Earning

\begin{abstract}
A B S T R A C T
Investors are facing doubt on the quality of earning reported. They require some indicators to detect the quality of earning reported. The use of past performance as indicators of current and future earning management is challengeable since there are contradicting results in the sign of the relationship between past performance and earning management. Another variable may moderate their relationship. Therefore, it is the purpose of this study to know if employee's relative earning is the moderating variable in the relationship between past performance and earning management. One hundred thirty-five companies listed in Indonesia Stock Exchange were selected with the use of stratified random sampling. The data is analyzed using sub-group analysis followed by the Chow $\mathrm{F}$ test and the linear regression analysis. Earning management is the dependent variable, whereas past performance is the independent variable, and employee relative earning is the moderating variable. The null hypotheses were rejected. A significant negative association exists between past performance and earning management, while the employee relative earning was found to be the moderating variable. The effect of past performance to earning management increases as employee relative earning getting lower.
\end{abstract}

\section{Introduction}

Earning management is a phenomenon where management uses either legal or sometimes illegal methods to attain particular earning goals (Tang et al., 2015). It is used to achieve a certain earning goal by manipulating corporate financial data (Ahadiat \& Hefzi, 2013; Bartov, Givoly, \& Hayn, 2002; Healy \& Wahlem, 1999). Many firms engage in earning management. Since there was a significant correlation between earning management and corporate performances (Al-Fayoumi, Abuzayed, \& Alexander, 2010; De Jong, Mertens, van der Poel, \& van Dijk, 2014; Francis, Hasan, \& Li, 2016; Kothari, Mizik, \& Roychowdhury, 2015; Zang, 2012;). In some studies, the correlation between earning management and firm performance was positive (Dakhlallh, at al., 2020; Gunny, 2010); Healy \& Wahlen 1999; Tang et al., 2015). While in other studies it showed a negative correlation between earnings management and corporate performance (Cohen \& Zarowin, 2010; Dakhlallh, at al., 2020; Graham, Harvey, \& Rajgopal, 2005; Kothari et al., 2015; Leggett, Parsons, \& Reitenga, 2016; Mahdavi Ardekani, Younesi, \& Hashemijoo, 2012; Tang \& Chang, 2015; Zhu, Lu, Shan, \& Zhang, 2015). It seems that the negative effect of earning management to performance exists in the long-term, while in the current and short term, the impact was positive (Dakhlallh, at al., 2020; Healy \& Wahlen, 1999; Rangan, 1998; Tang et al., 2015).

\footnotetext{
* Corresponding author.

E-mail address: rkountur@gmail.com (R. Kountur)
} 
According to the agency theory, the motive of doing earning management depends on the manager's interest that can affect shareholders' evaluation of their performance (DeFond \& Park, 1997; Kontesa, Brahmana \& Tong, 2020; Subramanyam, 1996). The other motive of having higher earning is to attract investors (Kumari \& Pattanayak, 2017). Managers influence investors by meeting profit targets and earnings projections (Sevin \& Schroeder, 2005). It conveys a positive signal about future performance to investors (Tucker \& Zarowin, 2006). Or, the manager used earnings management to boost his reputation (Zhang, Uchida, \& Bu, 2013). They got credit when they were able to forecast earning precisely (Williams, 1996), and to do that, they have to manipulate earning. As a result, engaging in earning management leads to the manipulation of the financial report (Kumari \& Pattanayak, 2017). The future and present revenue is affected by the present practices of earning management (Bautista et al., 2005). No wonder the market and investors were challenged by the quality, significance, and reliability of financial information due to the finance and accounting irregularity provided by companies (Tang et al., 2015). Investors and other parties who get interest in knowing financial statements will always face doubt on the quality and significance of the earning reports. Thus, it is essential to know ways of detecting the practices of earning management. It is the purpose of this study to know if past performance and employee relative earning can give some indications to the quality of earning reported.

\section{Literature Review}

\subsection{Earning Management and Past Performance}

Studies have shown that the use of earning management was to cover its past bad performance by increasing revenue (Habib, Uddin Bhuiyan, \& Islam, 2013). A company that experiences low earning in previous years tends to engage in earning management in the current and upcoming years. They need to meet the earning expectation of the firm (Bartov, Givoly, \& Hayn, 2002). The financial statement is then adjusted by executives to achieve the target (Healy \& Wahlem, 1999). Besides, there is enough evidence to show that the practices of earning management help prevent reporting losses (Gang, Zezhong, Travlos, \& Hong, 2007). Since it increases earnings (Gunny, 2010), increases the firm's profitability in the future (Siregar \& Utama, 2008), and the quality of earning itself (Jara \& Lopez, 2011). It provides better signal and performance in the future. However, the practice of earning management not only to improve earning but also to maintain high performance. As the study of Burgstahler and Dichev (1997) found that the practice of earning management was driven by a positive earnings report and consistent firm performance. The reason, because the management did not want to lose its image and need to guard its reputation. As we can see, there are contradictions results in the sign of association between past performance and earning management. Further study needs to be done to get a better explanation of the relationship. A moderating variable may exist in their relationship.

\subsection{Earning Management and Relative Earning}

The previous study indicated that earning management was related to the remuneration agreement (Healy, 1985). It was to obtain incentive, bonus, and compensation that lead managers to involve in earning management (Barth, Elliott, \& Finn, 1999; Chan et al., 2015; Cohen et al., 2008; Dechow \& Skinner, 2000; Healy, 1985; Watts, 2003; Watts \& Zimmerman, 1990; Zang, 2012). Studies had found a significant relationship between managerial incentive and earning management, including the study of Cheng \& Warfield (2005). One way of measuring incentives and compensation is to use relative earning. The study of Bai \& Cheng (2014) made use of the three measures of relative earning, which were the capital earnings relative to labor earnings, earning of high-level manger relative to ordinary workers, and overall average wage level relative to a firm's average wage level. The same study found that these relative earnings have significant effects on corporate performance. Therefore, we hypothesize that employee relative earning can be used to explain the relationship between past performance and earning management.

\subsection{Theoretical Framework}

Since contradiction results are found in the sign of the relationship between past performance and earning management, an explanation is needed. A moderating variable may exist in their relationship that can explain the sign of the association. Literature supports our hypothesis that the employee relative earning may be the moderating variable in the relationship between past performance and earning management, as shown in Figure 1. Aside from explaining the sign of the association between past performance and earning management, employee relative earning can be used by investors together with past performance to predict the quality of earnings reported.



Fig. 1. The moderating effect of employee relative earning on the relationship between past performance and earning management 
Based on the above literature review, we formulate the research hypotheses as follows: The first research hypothesis $\left(\mathrm{H}_{\mathrm{a} 1}\right)$ stated that past performance significantly relates to earning management. The second research hypothesis $\left(\mathrm{H}_{\mathrm{a} 2}\right)$ stated that employee relative earning is the moderating variable in the relationship between past performance and earning management.

\subsection{Purpose}

Investors were challenged by the quality and significant of financial information due to the accounting irregularity provided by companies (Tang et al., 2015). Investors seems to doubt in the quality of earning reported. They required some indicators to detect the earning quality reported. The use of past performance as indicators of current and future earning management is challenged since there is a contradicting result in the sign of the relationship between past performance. Some studies found negative relationship (Habib, Uddin Bhuiyan, \& Islam, 2013; Bartov, Givoly, \& Hayn, 2002); while other showed positive relationship (Burgstahler \& Dichev, 1997). Another variable may moderate their relationship. Therefore, it is the purpose of this study to know if employee relative earning is the moderating variable in the relationship between past performance and earning management.

\section{Method}

\subsection{Participants}

Companies listed in the Indonesian Stock Exchange in the year 2020 were selected to be the participant of this study. The stratified random sampling technique was used where the companies were divided into three groups of industry; they are, services, manufacturing, and trading. Each group of the industry was randomly selected 50 companies that made up of 150 companies participated in this study. This research is a cross-sectional study where data was taken from their financial statements in one particular period that is the year 2017 for past performance and 2018 for employee relative earnings and earning management. When data was analyzed, fifteen companies were removed due to missing data and were found to be the outlier. It then left 135 companies to be analyzed as the participants.

\subsection{Dependent Variable}

Earning management is the dependent variable in this study. Since there are several kinds of earning management, then the accrual-based earning management was used in this study. It was used as the degree of earning management practices. From literature, most of the earning management practices used the accrual earning management (Healy \& Wahlen, 1999; Fields, Lys, \& Vincent, 2001; Schipper, 1989). The extended model popularized by Kothari, Leone, \& Wasley (2005), and by Hashmi et al., (2018) used to calculate the accrual-based earnings management. The formula,

$$
\frac{T A C_{i t}}{T A_{i t-1}}=\propto_{0}+\propto_{1} \frac{1}{T A_{i t-1}}+\propto_{2} \frac{\Delta R E V_{i t}-\triangle R E C_{i t}}{T A_{i t-1}}+\propto_{3} \frac{P P E_{i t}}{T A_{i t-1}}+\propto_{4} R O A_{i t}+e_{i t}
$$

where: $\quad \mathrm{TAC}=$ total accruals; $\mathrm{TA}=$ total assets; $\alpha_{0}=$ constant; $\alpha=$ coefficient; $\mathrm{REV}=$ revenue; $\mathrm{REC}=$ receivables; $\mathrm{PPE}=$ plant, property, and equipment; ROA $=$ return on assets; and $\mathrm{e}=$ error.

\subsection{Independent Variable}

Past performance is the independent variable of this study. The revenue growth of time t-1 measures past performance. It is the revenue of time $\mathrm{t}-1$ minus the revenue of time $\mathrm{t}-2$ divided by the revenue of time $\mathrm{t}-2$. It is computed as,

$$
\left(\mathrm{REV}_{\mathrm{t}-1}-\mathrm{REV}_{\mathrm{t}-2}\right) / \mathrm{REV}_{\mathrm{t}-2} \text {. }
$$

where: $\mathrm{REV}_{\mathrm{t}-1}=$ revenue at time $\mathrm{t}-1 ; \mathrm{REV}_{\mathrm{t}-2}=$ revenue at time $\mathrm{t}-2$.

\section{Moderating Variable}

The moderating variable of this study is employee relative earning. Three measure used in measuring relative earning, they are capital earnings relative to labor earning, earnings of high-level managers relative to ordinary workers and overall average wage level relative to a firm's average wage level (Bai \& Cheng, 2014). However, in this study, we were using the employee relative earning instead of relative earning. The employee relative earning is derived from the salary of time $t$ divided by the revenue of time t-1. It is computed as,

$$
\mathrm{REE}_{\mathrm{t}}=\mathrm{W}_{\mathrm{t}} / \mathrm{REV}_{\mathrm{t}-1}
$$

where: $\mathrm{REE}_{t}=$ employee relative earning at time $t ; \mathrm{W}_{t}=$ wages and salary expenses at time $t$; and $\mathrm{REV}_{\mathrm{t}-1}=$ revenue at time $t-1$. 


\subsection{Statistical Analysis}

In testing the first hypothesis, the ordinary linear regression analysis is used. While in testing the second hypothesis, the subgroup moderating analysis is used, followed by the F-Chow test. It was to test the moderating effect of employee relative earning on the relationship between past performance and earning management. The formula for F-Chow test is:

$\mathrm{F}_{\text {Chow }}=\frac{\{R S S T-(R S S 1+R S S 2)}{(R S S 1+R S S 2 /(n 1+n 2-2 k)}$

where: $\quad \mathrm{F}_{\text {Chow }}=$ Choi test; $\mathrm{RSST}=$ residual sum of square total; RSS1 = residual sum of square group $1 ;$ RSS2 $=$ residual sum of square group $2 ; \mathrm{n} 1=$ total number of respondents in group $1 ; \mathrm{n} 2=$ total number of respondents in group 2 ; and $\mathrm{k}=$ number of coefficients including the constant.

For the employee relative earning to be the moderating variable, $\mathrm{F}_{\text {Chow }}$ computed must be higher than the $\mathrm{F}$ table at a degree of freedom $\mathrm{k} / \mathrm{n} 1+\mathrm{n} 2-2 \mathrm{k}$.

\section{Results}

\subsection{Descriptive Analysis}

We were using the accrual-based earning management technique to measure the quality of earning. It was a popular proxy in determining the degree of earning management. Most of the company listed in Indonesia Stock Exchange (43.7\%) had an average quality of earning, in the sense that the scores were around zero, that was between -0.075 to 0.029 , see Table 1 . A positive score indicates the low quality of earning. The higher the score, the lower is the quality of earning, and the more intent is the practice of earning management. Less than one-fourth of the companies $(17.8 \%)$ practice earning management. In terms of past performance, that was measured by revenue growth, most of them $(60.7 \%)$ had revenue growth range around zero from -0.421 to 0156 , followed by quite high growth $(25.9 \%)$ that was ranged from 0.157 to .734 . However, some but few of them had declining growth (5.2\%). In terms of employee relative earning, most of them had a very low employee relative earning $(75.6 \%)$.

\section{Table 1}

The mean, standard deviation, frequency, and percentage of companies listed in Jakarta Stock Exchange.

\begin{tabular}{|c|c|c|c|c|}
\hline & Mean & SD & Frequency & Percent \\
\hline Earning Management & -0.054 & 0.119 & - & - \\
\hline $0.135<$ & & & 7 & 5.2 \\
\hline $0.030-0.134$ & & & 17 & 12.6 \\
\hline$-0.075-0.029$ & & & 59 & 43.7 \\
\hline$-0.180--0.076$ & & & 39 & 28.9 \\
\hline$-0.285--0.181$ & & & 8 & 5.9 \\
\hline$-0.390--0.286$ & & & 2 & 1.5 \\
\hline$-0.495--0.391$ & & & 2 & 1.5 \\
\hline$-0.600--0.496$ & & & 1 & 0.7 \\
\hline Past Performance & 0.182 & 0.509 & - & - \\
\hline $3.047<$ & & & 1 & 0.7 \\
\hline $1.891-2.468$ & & & 1 & 0.7 \\
\hline $1.313-1.890$ & & & 2 & 1.5 \\
\hline $0.735-1.312$ & & & 7 & 5.2 \\
\hline $0.157-0.734$ & & & 35 & 25.9 \\
\hline$-0.421-0.156$ & & & 82 & 60.7 \\
\hline$-0.999--0.422$ & & & 7 & 5.2 \\
\hline Emp. Rel. Earning & 0.163 & 0.257 & - & - \\
\hline $1.106<$ & & & 3 & 2.2 \\
\hline $0.948-1.105$ & & & 2 & 1.5 \\
\hline $0.790-0.947$ & & & 5 & 3.7 \\
\hline $0.474-0.631$ & & & 1 & 0.7 \\
\hline $0.316-0.473$ & & & 4 & 3 \\
\hline $0.158-0.315$ & & & 18 & 13.3 \\
\hline $0.000-0.157$ & & & 102 & 75.6 \\
\hline
\end{tabular}




\subsection{Sub-Group Moderating Analysis}

A multiple linear regression analysis was used in testing the null hypothesis that past performance has no relationship with earning management. The null hypothesis was rejected $(\beta=-0.077, \mathrm{p}<0.05)$ at significant level of 0.05 , see Table 2 . There was a significant negative association between past performance and earning management. As past performance getting lower, earning management practices tend to increase. The null hypothesis that employee relative earning has no relationship with earning management was rejected $(\beta=-0.074, p<0.10)$ at a significant level of 0.10 . About $10.3 \%$ change in earning management was due to past performance and employee relative earning.

Table 2

Significant of past performance and employee relative earning toward earning management

\begin{tabular}{lccccc}
\hline & Beta Coef. & P-value & $\mathrm{R}^{2}$ & Adj. $\mathrm{R}^{2}$ & F sig. \\
\hline Past Performance & -0.077 & 0 & & & \\
& & & 0.117 & 0.103 & 0.000 \\
Employee Relative Earning & -0.074 & 0.055 & & & \\
\hline
\end{tabular}

The null hypothesis that employee relative earning cannot be used as the moderating variable in the relationship between past performance and earning management was tested with the use of the sub-group analysis. The data were grouped into two groups based on the average employee relative earning score. The first group was the past performance and the earning management that had employee relative earning scores below average, and the second group was the past performance and the earning management that had employee relative earning scores above average. The $\mathrm{R}^{2}$ of the first group $(0.154)$ was higher than the $\mathrm{R}^{2}$ of the second group (0.086), see Table 3. It indicated the existence of a moderating effect. However, this method had some critiques; therefore, further analysis with the Chow test was needed.

Table 3

The sub-group and total R square, residual sum of square (RSS), number of the respondent (n), dan P-value

\begin{tabular}{lcccc}
\hline & $\mathrm{R}^{2}$ & $\mathrm{RSS}$ & $\mathrm{n}$ & P-value \\
\hline Group 1 & 0.154 & 1.15 & 102 & 0.000 \\
Group 2 & 0.086 & 0.446 & 33 & 0.097 \\
\hline Total & 0.092 & 1.741 & 135 & 0.000 \\
\hline
\end{tabular}

The Chow test was used to test the moderating effect of employee relative earning in the relationship between past performance and earning management. It was found that the computed F-Chow $(\mathrm{F}(4,131)=11.95)$ was higher than the table $\mathrm{F}(\mathrm{F}(3,129)=$ 3.984). Therefore, the null hypothesis is rejected. Employee relative earning had a moderating effect on the relationship between past performance and the earning management practices. As the wages and salary expenses as compared to last year's revenue decrease $(\beta=-0,074)$, the effect of past performance to earning management practices is getting stronger. When comparing the result of linear regression analysis between past performance and earning management without and with employee relative earning was found to be different. The $R^{2}$ with employee relative earning $\left(R^{2}=0.103\right)$ is higher than the $R^{2}$ without employee relative earning $\left(\mathrm{R}^{2}=0.092\right)$. It shows that as an employee earning getting lower, the effect of past performance on the practice of earning management was getting stronger.

\section{Discussion}

Most companies listed in Indonesia Stock Exchange (IDX) seems to have stagnant revenue growth. Though some have negative growth and others have positive growth but they are close to zero. Few have negative growth. When it is combined with the low employee relative earning as indicated in our finding, we expect the earning management to be higher. But not many of them have lower quality of earning. Most companies listed in IDX have an average quality of earning. However, we found that a significant negative correlation exists between past performance and earning management. And that the strength of their relationship getting stronger as employee relative earning getting smaller. This finding is supported by the result of previous studies that incentives and bonuses affect the practices of earning management (Barth, Elliott, \& Finn, 1999; Dechow \& Skinner, 2000; Healy, 1985). Companies need to look at the incentive and bonus given to their employee. When those incentives and bonuses had a connection with the company's performance, then we may expect it to affect the quality of earning reported. It is because when management considers his wages and salary as low and the growth of the company's past revenue decline, they are forced to do earning management. It is to increase the incentive and bonuses they received. Thus, as past performance decline and is combined with low employee relative earning will lead management to manipulate earnings. For investors and market analysts, employee relative earning that is combined with past corporate performance could be used to predict the quality of earnings reported. Earning management not only affects the performance of current year but also the years ahead (Bartov, 
Givoly, \& Hayn, 2002). Therefore, early detection of earning management is essential. Looking back at the previous revenue performance may indicate the current and future practices of earning management. As our study suggests that past revenue performance and employee relative earning may be used to indicate the practices of earning management. When past performance is poor, as previous studies had found too, management tends to increase revenue to meets it earning expectation by practicing earning management (Bartov, Givoly, \& Hayn, 2002; Gang, Zezhong, Travlos, \& Hong, 2007; Habib, Uddin Bhuiyan, \& Islam, 2013; Healy and Wahlem, 1999; Watts, 2003).

\section{Conclusion}

It is important for investors and others who are interested in the earning performances of a firm to consider the firm's past performance. It determines the current and future quality of its reported earnings. However, employee relative earnings need to be considered too since it strengthens the effect of a firm's past performance on the quality of its reported earning as the essential proxy of earning management. This study is without limitations. When it comes to measuring past performance, we focus on the past growth of revenue. Therefore, we recommend further research with the use of different measurements of the past performance and different moderating variables.

\section{Acknowledgement}

The authors would like to thank the anonymous referees for constructive comments on earlier version of this paper.

\section{References}

Ahadiat, N., \& Hefzi, H. (2013). An investigation of earnings management practices: examining Generally Accepted Accounting Principles. International Journal of Business and Social Science, 3(14).

Al-Fayoumi, N., Abuzayed, B., \& Alexander, D. (2010). Ownership structure and earnings management in emerging markets: The case of Jordan. International Research Journal of Finance and Economics, 38(1), $28-47$.

Bai, P. \& Cheng, W. (2014). Relative earnings and firm performance: Evidence from publicly-listed firms in China $2005-2012$. Monas Business School. Discussion paper 51/14.

Barth, M. E., Elliott, J. A., \& Finn, M. W. (1999). Market rewards associated with patterns of increasing earnings. Journal of Accounting Research, 37(2), 387-413.

Bautista, J. M. S., Tangsoc, J. C., Cohen, D. A., Zarowin, P., Bergstresser, D., Philippon, T., ... Hooy, C. W. (2018). Evidence on the trade-off between real activities manipulation and accrual-based earnings management. Journal of Accounting and Public Policy, 30(2), 675-703.

Burgstahler, D., \& Dichev, I. (1997). Earnings management to avoid earnings decreases and losses. Journal of Accounting and Economics, 24(1), 99-126.

Chan, L.H., Chen, K.C.W., Chen, T.Y., \& Yu, Y. (2015). Substitution between real and accruals-based earnings management after voluntary adoption of compensation clawback provisions. The Accounting Review, 90 (1), $147-174$.

Cheng, Q., \& Warfield, T.D. (2005). Equity incentives and earnings management. The Accounting Review, 80 (2), $441-476$.

Cohen, D.A., Dey, A., \& Lys, T.Z., 2008. Real and accrual-based earnings management in the pre- and post-Sarbanes-Oxley periods. The Accounting Review, 83(3), 757-787.

Cohen, D. A., \& Zarowin, P. (2010). Accrual-based and real earnings management activities around seasoned equity offerings. Journal of Accounting and Economics, 50(1), 2-19. https://doi.org/10.1016/j.jacceco.2010.01.002

Dakhlallh, M.M., Rashid, N., Abdullah, W.A.W., Qawqzeh, H.K., \& Dakhlallh, A.M. (2020). Accrual-based earnings management, real earnings management and firm performance: Evidence from public shareholders listed firms on Jordanian's stock market. Journal of Advanced Research in Dynamical and Control System,12(1), 16-27.

De Fond, M. L., \& Park, C. W. (1997). Smoothing income in anticipation of future earnings. Journal of Accounting and Economics, 23(2), 115-139.

De Jong, A., Mertens, G., van der Poel, M., \& van Dijk, R. (2014). How does earnings management influence investor's perceptions of firm value? Survey evidence from financial analysts. Review of Accounting Studies, $19(2), 606-627$.

Dechow, P. M., \& Skinner, D. J. (2000). Earnings management: Reconciling the views of accounting academics, practitioners, and regulators. Accounting Horizons, 14(2), 235-250.

Fields, T. D., Lys, T. Z., \& Vincent, L. (2001). Empirical research on accounting choice. Journal of Accounting and Economics, 31(1-3), 255-307.

Francis, B., Hasan, I., \& Li, L. (2016). Abnormal real operations, real earnings management, and subsequent crashes in stock prices. Review of Quantitative Finance and Accounting, 46(2), 217-260. https://doi.org/10.1007/s11156-014-0468-y

Gang, W., Zezhong, X., Travlos, N., \& Hong, Z. (2007). Background of independent directors and corporate performance [J]. Economic Research Journal, 3. 
Graham, J. R., Harvey, C. R., Rajgopal, S. R. (2005). The economic implications of corporate financial reporting. Journal of Accounting and Economics, 40(1-3), 3-73.

Gunny, K. A. (2010). The relation between earnings management using real activities manipulation and future performance: Evidence from meeting earnings benchmarks. Contemporary Accounting Research, 27(3), 855-888.

Habib, A., Uddin Bhuiyan, B., \& Islam, A. (2013). Financial distress, earnings management and market pricing of accruals during the global financial crisis. Managerial Finance, 39(2), 155-180.

Hashmi, M. A., Brahmana, R. K., \& Lau, E. (2018). Political connections, family firms and earnings quality. Management Research Review, 41(4), 414-432.

Healy, P. M. (1985). The effect of bonus schemes on accounting decisions. Journal of Accounting and Economics, 7(1-3), 85107.

Healy, P. M., \& Wahlen, J. M. (1999). A review of the earnings management literature and its implications for standard setting. Accounting Horizons, 4, 365-383.

Jara, M. \& López, F.J. (2011). Earnings management and contests for control : An analysis of European family firms. Journal of CENTRUM Cathedra, 4(1), 100-120.

Kontesa, M., Brahmana, R., \& Tong, A.H.H. (2020). Narcissistic CEOs and their earnings management. Journal of Management and Governance, 07 March 2020.

Kothari, S. P., Leone, A. J., \& Wasley, C. E. (2005). Performance matched discretionary accrual measures. Journal of Accounting and Economics, 39(1), 163-197.

Kothari, Stephen P, Mizik, N., \& Roychowdhury, S. (2015). Managing for the moment: The role of earnings management via real activities versus accruals in SEO valuation. The Accounting Review, 91(2), 559-586

Kumari, P., \& Pattanayak, J. K. (2017). Linking earnings management practices and corporate governance system with the firms' financial performance: A study of Indian commercial banks. Journal of Financial Crime, 24(2), 223-241.

Leggett, D. M., Parsons, L. M., \& Reitenga, A. L. (2016). Real earnings management and subsequent operating performance. IUP Journal of Operations Management, 15(4).

Mahdavi Ardekani, A., Younesi, N., \& Hashemijoo, M. (2012). Acquisition, earnings management and firm's performance: Evidence from Malaysia. Journal of Business Studies Quarterly, 4(1), 91-110.

Rangan, S. (1998). Earnings management and the performance of seasoned equity offerings. Journal of Financial Economics, 50(1), 101-122.

Schipper, K. (1989). Earnings management. Accounting Horizons, 3(4), 91.

Sevin, S., \&Schroeder, R. (2005). Earnings management: evidence from SFAS No. 142 Reporting. Managerial Auditing Journal, 20(1), 47-54.

Siregar, S. V., \& Utama, S. (2008). Type of earnings management and the effect of ownership structure, firm size, and corporate governance practices: evidence from Indonesia. The International Journal of Accounting, 43, 1-27.

Subramanyam, K. R. (1996). The pricing of discretionary accruals. Journal of Accounting and Economics, 22(1-3), 249-281.

Tang, H. W., Chang, C. C., Gunny, K. A., Ge, W., Kim, J. B., Mahdavi Ardekani, A., ... Ngo, T. (2015). Real earnings management and future profitability: Measurement of real earnings management's current net income impact, crosssectional variation in real Earni Ngs management's effect on future profitability, and market participant response by Eric. Journal of Banking and Finance, 34(1), 317-339.

Tucker, J. W., \& Zarowin, P. A. (2006). Does income smoothing improve earnings informativeness? The Accounting Review, $81(1), 251-270$.

Watts, R.L. (2003). Conservatism in Accounting Part I: Explanations and Implications. Accounting Horizons, 17(3), $207-221$.

Watts, R. L., \& Zimmerman, J. L. (1990). Positive accounting theory: a ten year perspective. The Accounting Review, 65(1), 131-156.

Williams, P. A. (1996). The relation between a prior earnings forecast by management and analyst response to a current management forecast. The Accounting Review, JNBB, 71(1), 103-115.

Zang, A. Y. (2012). Evidence on the trade-off between real activities manipulation and accrual-based earnings management. Accounting Review, 87(2), 675-703.

Zhu, T., Lu, M., Shan, Y., \& Zhang, Y. (2015). Accrual-based and real activity earnings management at the back door: evidence from Chinese reverse mergers. Pacific-Basin Finance Journal, 35(12), 317-339. 


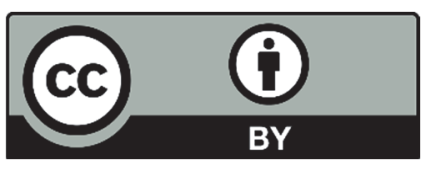

(C) 2021 by the authors; licensee Growing Science, Canada. This is an open access article distributed under the terms and conditions of the Creative Commons Attribution (CC-BY) license (http://creativecommons.org/licenses/by/4.0/). 